Article

\title{
The Relationship between Self-City Brand Connection, City Brand Experience, and City Brand Ambassadors
}

\author{
Eunah Yu and Junghyun Kim * \\ Department of Advertising and Public Relations, Chung-Ang University, Seoul 06974, Korea; win0916@cau.ac.kr \\ * Correspondence: jhkim@cau.ac.kr; Tel.: +82-02-820-5817
}

Received: 16 December 2019; Accepted: 27 January 2020; Published: 29 January 2020

check for updates

\begin{abstract}
The city brand experience of residents has emerged as an important topic due to the concentration of the city population and changes in the marketing environment. This study examined the relationship between self-city brand connection, city brand experience, city brand satisfaction, and city brand ambassadorship behavior intention (CBABI) in city residents. An empirical analysis was conducted using data collected through a questionnaire with 328 residents of Seoul and Busan in Korea. The results reveal that self-city brand connection is positively related to city brand experience and city brand satisfaction but is not directly related to CBABI. Next, city brand experience was found to have a significant positive relationship with city brand satisfaction and CBABI, and city brand satisfaction is positively related to CBABI. We also found differences in the effects of city brand satisfaction on CBABI between Seoul and Busan. Although city brand satisfaction had a significant effect on CBABI in both cities, the effect was greater in Busan. This study confirms the effect of citizens' city brand experiences and identifies the path by which city residents become city brand ambassadors.
\end{abstract}

Keywords: city branding; city brand experience; self-city brand connection; city brand satisfaction; city brand ambassadorship behaviors intention

\section{Introduction}

According to a report published by the United Nations Human Settlements Program in 2018, the world's city population will grow steadily, and $60 \%$ of the total population will be living in cities and urban areas by 2030. Between 2010 and 2025, city populations internationally are expected to grow from 2.5 to 3 billion. According to the 2017 Census data, 50\% of Korea's population lives in Seoul, Gyeonggi, and Incheon, and $92.8 \%$ of the total population live in cities.

Accordingly, population concentration in cities has accelerated, and interest in cities has increased. City branding is becoming more heated as cities attempt to differentiate themselves from others and establish unique identities, especially in the face of fierce global competition [1]. City branding has long received attention in academia and practice. The concept of city branding has actively adopted strategies that have been accepted in product marketing and brand strategy since the early 2000s, and various concepts related to brand strategy have been applied to city branding [2]. Such concepts include city brand assets [3], personality [4,5], identity [6], and reputation [7], which have been extensively studied concerning city brands.

In recent years, city branding has also faced new challenges in the changing marketing environment. If city branding previously focused on how to make a city more attractive to tourists and investors, the recent focus is on residents, who have become the most important factor [8]. Residents themselves could be a city asset, and thus, city brand management should consider consumer-oriented branding. Furthermore, residents should be targeted so that their perceptions play a key role in city branding [9]. 
According to a study on the role of residents in city branding [10], residents have three major roles. First, residents are the subjects of city branding. As city policy is formulated according to citizens' decisions, residents become the decision-makers in city branding. Second, residents can be a key element of city branding as today, when tourists visit a city, they consider not only the external attributes of the city but also the lives of the residents in evaluating the value of their visit. Finally, residents can be brand ambassadors for their city in the same way a satisfied consumer can generate positive word-of-mouth reviews of a company, which can affect not only their repurchase intention or satisfaction as a brand evangelist but also impact others.

Presently, the concept of city branding is changing rapidly, and challenges are accelerating. As mentioned, many studies on city brand assets, personality, and image have borrowed existing concepts of brand research. In the marketing field, consumer experiences emerge as the most important issue for companies, and in the face of intense competition, experience is already replacing product quality [11]. Although brand experience has gained attention in marketing and brand-related fields, it is a new concept in sectors such as travel and tourist attractions [12]. Efforts have been made to expand and integrate the idea of brand experience in marketing with those of city-, destination-, and tourist-destination-related experiences, but some are at an early stage. Thus, this study examines the effect of a city's brand experience and the preceding factors influencing it.

This study is distinct from previous studies in two ways. First, it seeks to identify the leading variables of city brand experience for residents who live in cities. Second, it examines the preceding variables that influence city brand ambassadorship behavior intention concerning the participation of citizens. This study provides specific guidance on the continued growth of cities and citizens' happiness by identifying how city residents experience their city and how this affects their participation and satisfaction.

\section{Literature Review and Research Framework}

\subsection{City Brand Experience}

Brand research is one of the many concepts that city brand experience research has borrowed from brand research. The concept of brand experience includes the direct purchase or use of products, and indirect experiences with the brand, such as advertisements or website visits and exposure to various brand-related stimuli [13]. A common belief regarding brand experience is that it is expressed by the interaction between the consumer and the brand [13-15]. According to Brakus et al. [13], brand experiences differ from other concepts related to brand constructs. Brand experience, in particular, was found to differ from evaluative or emotional concepts. In other words, the brand experience can occur even when the consumer has no personal involvement or connection with the brand. Involvement or brand connection occurs when the consumer has a deep emotional involvement in the brand, but brand experience is a consumer's response, which differs from the emotional connection or the evaluative judgment.

Previous studies have suggested different constructional dimensions for brand experience. However, the argument for a common dimension is that brand experience is multi-dimensional rather than unidimensional. According to a scale development study on brand experience [13], which is a relatively recent study that has been cited in many other studies, brand experience consists of four dimensions.

The first is sensory experience, which corresponds to the response by sensory organs induced by brands. Second, emotional experience corresponds to the emotional response that consumers feel toward the brand, which can be viewed as a dimension that affects the formation of emotional ties between the consumer and brand. Third, behavioral experience corresponds to behavioral and physical responses that consumers experience through the brand. Fourth, cognitive experience induces diffuse thinking and analytical reasoning regarding the brand [14,15]. 
Although brand experience has been attracting attention in marketing and brand-related fields, it is considered a new concept in areas such as place branding [12]. Some studies [12,16] have attempted to extend the brand experience in marketing to the experience of a city, destination, or tourist destination. In previous studies, Barnes et al. [12] applied the dimension of the brand experience presented by Brakus et al. [13] to tourist attractions to verify the validity of dimensions and measures. Moreover, Kumar and Kanshik [16], in an extension of this study, explored the impact of a destination's brand experience on regional brand identity, trust, and loyalty. The above studies examined whether the four brand experience dimensions and measurement tools presented in the study of Brakus et al. [13] can apply to a new tourist destination or destination. According to the research, the validity and reliability of the scale are supported within the new destination brand context. The experience of cities is generally formed by interactions with tourist destinations, tourist companies, and city residents [17]. However, previous studies on city brand experience have only focused on tourist-based experience $[16,18]$. This study is distinct in its focus on the experience of city residents; it integrates the concept and dimension of brand experience with city brand experience.

\subsection{Self-City Brand Connection}

Consumers build relationships with brands as they experience products and services. Strong brands provide value for consumers, and through this process, consumers may build emotional bonds with brands. When consumers choose a brand, they choose a product or brand that is similar to their images, and the emotional combination of the consumer and the brand has a positive effect on the consumer response [19].

In city branding, a city resident is not just a passive beneficiary, but an active partner and co-producer $[20,21]$. As the role of residents in city branding increasingly strengthens, this study focuses on the brand connection between residents and the city as a leading variable influencing the city brand experience. Consumers have a sense of connection through their own-brand consensus, and this connection shows that a brand can become a symbol in itself and part of the consumer [22]. Previous studies have suggested self-brand connections as important drivers of emotional experiences with brands [23,24]. Furthermore, in place branding, attitudes toward the place brand, perceived quality, and brand uniqueness have a positive effect on the place-brand connection of the residents, and the city-brand connection influences their advocacy of the place [25].

Therefore, we propose the following hypotheses.

Hypothesis 1 (H1): Self-city brand connection will positively influence city brand experience.

Hypothesis 2 (H2): Self-city brand connection will positively influence city brand satisfaction.

Hypothesis 3 (H3): Self-city brand connection will positively influence city brand ambassadorship behavior intention.

\subsection{Effects of City Brand Experience}

Satisfaction has been treated as a central research topic in various disciplines, but research on satisfaction is very limited in city brand research [26]. A study on the satisfaction of urban residents showed that satisfaction can be conceptualized as a positive response concerning the emotional and cognitive aspects of the place of residence [27].

To examine the effect of tourists' brand experience on satisfaction and loyalty toward tourist destinations, Barnes et al. [12] applied brand experience as presented by Brakus et al. [13]. The results revealed that the brand experience for tourist attractions had a positive effect on satisfaction and loyalty. In an extension of this study, Kumar and Kanshik [17] examined the impact of destination 
brand experience on local brand identity, trust, and loyalty. The results indicate that destination brand experiences have a positive effect on trust and loyalty.

This study also predicts that city brand experience will encourage city residents to participate in activities related to their cities. Recently, city branding has been conducted based on the active participation of citizens; branding activities, which had been the area of experts, are developing in the direction of citizens' participation, sharing, and enjoyment value [28]. Studies on city sustainability $[29,30]$ have argued that sustainability can be realized through citizen participation and collaboration in the city with the concept of participatory governance. Similarly, the satisfaction and participation of urban residents is important to sustainability in urban branding in the face of fierce competition between cities due to the free movement of capital and markets [28,31]. Participation in city branding by residents, in particular, leads to successful city branding by enhancing ownership and sense of belonging to the city [32]. Consequently, successful urban branding promises residents' well-being and urban sustainability [31].

Resident engagement in city branding can be found in the role of a brand ambassador. Brand ambassadors generally refer to people who are passionate about an organization or brand and are engaged in activities that give consumers a meaning about brand [33]. Brand ambassadors in a business can generate repurchase or satisfaction among customers, as well as positive word of mouth that can affect others in place branding [34]. Research that identifies the role of a place brand ambassador shows that they have a variety of information and experiences about their place of residence and communicate this information to others through their networks or means. Place brand ambassadors can also act as endorsements to attract others to visit their place of residence. An endorsement is usually responsible for promoting a product or service and its sale, and the place brand ambassador is also responsible for facilitating visits to their place of residence [35]. Therefore, city brand ambassadorship behavior can be defined as sharing positive experiences about the residents' city through word-of-mouth and advocating for it [10]. Social values and the connections between residents were found to be the main motivations for being a city brand ambassador [8].

Positive attitudes and high perceived quality of the city has a positive effect on the satisfaction of residents, which has been found to have a positive effect on the intention to act as a city ambassador [36]. Therefore, we formulate the following hypotheses.

Hypothesis 4 (H4): City brand experience will positively influence city brand satisfaction.

Hypothesis 5 (H5): City brand experience will positively influence city brand ambassadorship behavior intention.

Hypothesis 6 (H6): City brand satisfaction will positively influence city brand ambassadorship behavior intention.

Our proposed research model, based on the above hypotheses, is given in Figure 1. 


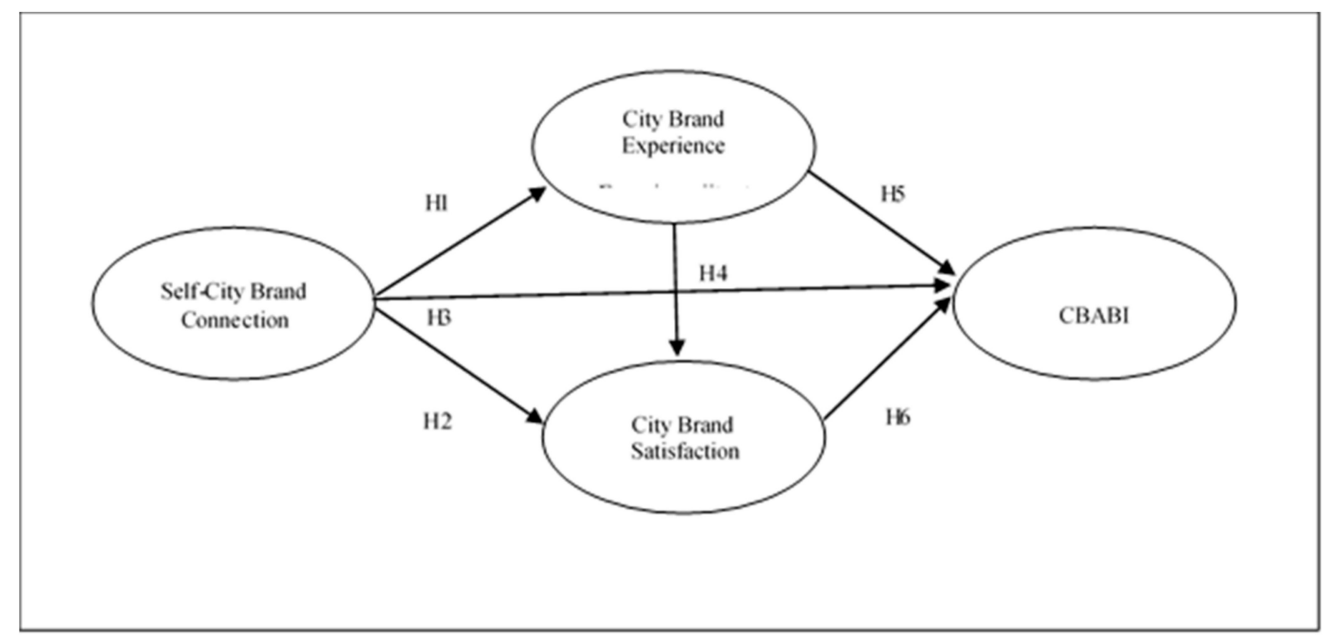

Figure 1. Research model and hypotheses.

\section{Methods}

\subsection{Participants and Data Collection}

In a study on the effect of city brand experience on city brand awareness, Choi et al. [37] suggested that metropolitan cities could ensure the representativeness and generality of large cities with populations of more than one million people. To maintain the representativeness of cities, the current study focused on residents living in Seoul and Busan for more than a year. The population of Seoul is 9.7 million and that of Busan is 3.34 million (UN Census Report 2017).

To test the hypotheses, data were collected with the help of a structured questionnaire using convenience sampling. Participants were recruited through an online survey company in Seoul, Korea. The company's researchers sent emails to their panels and those wishing to participate could do so by clicking on the link included in the email. A total of 328 people participated in the questionnaire survey.

The survey was conducted from March 23 to March 27, 2019. To ensure accurate representation, six demographic variables were considered in choosing the panel: residence (Seoul: 156, Busan: 172), gender (female: 167, male: 161), age (19-29: 30.8\%; 30-39: 35.4\%, $\mathrm{M}=35.10, \mathrm{SD}=8.318$ ), marital status (single: $66.5 \%$; married: 33.5\%), occupation (office worker: 49.7\%; housewife: 2.1\%; professional: $15.5 \%$; student: $14.9 \%$; sales or service worker: $7.6 \%$; and other: $10.1 \%$ ), and education levels that are reflective of the general female population in the same age range (college: $78.7 \%$; high school: $9.8 \%$; and graduate school: $11.5 \%$ ). The average amount of time that respondents had lived in their city was 30.5 months. Table 1 reports the characteristics of the respondents.

Table 1. Demographic characteristics of respondents.

\begin{tabular}{|c|c|c|c|}
\hline & Characteristics & N (328) & $\%(100)$ \\
\hline \multirow[t]{2}{*}{ City } & Seoul & 156 & 47.6 \\
\hline & Busan & 172 & 52.4 \\
\hline \multirow[t]{2}{*}{ Gender } & Male & 161 & 49.1 \\
\hline & Female & 167 & 50.9 \\
\hline \multirow[t]{3}{*}{ Age } & $20-29$ & 101 & 30.8 \\
\hline & $30-39$ & 111 & 33.8 \\
\hline & 40-49 & 116 & 35.4 \\
\hline \multirow[t]{3}{*}{ Education } & High school & 32 & 9.8 \\
\hline & University & 258 & 78.7 \\
\hline & Graduate school & 38 & 11.5 \\
\hline \multirow[t]{2}{*}{ Marital status } & Married & 110 & 33.5 \\
\hline & Single & 218 & 66.5 \\
\hline
\end{tabular}


Table 1. Cont.

\begin{tabular}{cccc}
\hline & Characteristics & N (328) & \% (100) \\
\hline Occupation & Office worker & 163 & 49.7 \\
& Professional & 51 & 15.5 \\
& Student & 49 & 14.9 \\
& Sales/ Service & 25 & 7.6 \\
& Homemaker & 7 & 2.1 \\
Monthly personal income $\left(\right.$ KRW $^{1}{ }^{\text {) }}$ & Other & 33 & 10.1 \\
& Less than 1 million & 67 & 20.4 \\
& 1-1.999 million & 62 & 18.9 \\
& 2-2.999 million & 99 & 30.2 \\
Residence period (months) & 3-3.999 million & 51 & 15.5 \\
& 4 million or greater & 49 & 14.9 \\
& Seoul & $\mathrm{M}=29.51, \mathrm{SD}=10.559$ \\
& Busan & $\mathrm{M}=31.48, \mathrm{SD}=8.962$ \\
\hline
\end{tabular}

${ }^{1}$ US\$ 1 = KRW (Korean Won) 1100.

\subsection{Measures}

All measurement items were adapted from the literature and were assessed using a seven-point Likert-type scale ranging from $1=$ strongly disagree to $7=$ strongly agree. City brand experience was measured based on twelve items adapted from Brakus et al. [13] and Barnes et al. [12]; self-city brand connection was measured using three items adapted from Escalas and Bettman [23] and Kemp et al. [25]. City brand satisfaction was measured using three items adapted from Zenker and Rütter [26] and Klaus and Maklan [11]. City brand ambassadorship behavior intention was measured using four items adapted from Zenker and Rütter [26] and Taecharungroj [36]. To provide the most appropriate measurement items for respondents in Korea, we revised the wording of some items. The items are listed in Table 2.

Table 2. Measurement items.

\begin{tabular}{|c|c|c|}
\hline Construct & Measurement Items & Source \\
\hline $\begin{array}{c}\text { City } \\
\text { Brand } \\
\text { Experience }\end{array}$ & $\begin{array}{c}\text { This city makes a strong impression on my senses, visually and in other ways. } \\
\text { I find this interesting in a sensory way. } \\
\text { This city does not appeal to my senses. * } \\
\text { This city induces feelings and sentiments in me. } \\
\text { I do not have strong emotions for this city. } \\
\text { This city is an emotional place for me. } \\
\text { I engage in physical activities and behaviors when I am in this city. } \\
\text { This city is not activity oriented. * } \\
\text { I think a lot when I am in this city. } \\
\text { This city does not make me think. }{ }^{*} \\
\text { This city stimulates my curiosity and problem-solving skills. }\end{array}$ & {$[10,13]$} \\
\hline $\begin{array}{l}\text { City Brand } \\
\text { Ambassadorship } \\
\text { Behavior Intention }\end{array}$ & $\begin{array}{l}\text { I am willing to recommend the city to people (prospective residents, visitors, } \\
\text { businesses) who seek my advice. } \\
\text { I would encourage other people (prospective residents, visitors, businesses) to } \\
\text { come to the city. } \\
\text { I will attend meetings and offer opinions to improve the city. }\end{array}$ & {$[28,29]$} \\
\hline $\begin{array}{l}\text { City Brand } \\
\text { Satisfaction }\end{array}$ & $\begin{array}{l}\text { Overall, I like living in this city. } \\
\text { I feel that this city is a good and livable city. } \\
\text { I am satisfied with the city I live in. }\end{array}$ & {$[11,29]$} \\
\hline $\begin{array}{l}\text { Self-City brand } \\
\text { Connection }\end{array}$ & $\begin{array}{c}\text { I can identify with this city. } \\
\text { This city reflects who I am. } \\
\text { I feel a personal connection with this city. } \\
\text { I consider this city to reflect whom I consider myself to be. }\end{array}$ & {$[26,36]$} \\
\hline
\end{tabular}

Note: ${ }^{*}$ reverse-code. 


\subsection{Analysis Method and Procedure}

Descriptive statistics, correlation analysis, and reliability analysis were performed using SPSS 20. AMOS 20 was then used to verify the validity of the measurement tool and to test our hypotheses. For further examination, multi-group analysis using cross-group equality constraints was conducted to verify whether the groups in Seoul and Busan differ. Kline [38] suggested the moderating effect could be checked by testing the same model for each of the different samples and then comparing the non-standardized coefficients. The moderator was tested by specifying restrictions for equality between groups (cross-group equality constraints). The constrained fit model was compared with the free fit model using the chi-square difference statistic. Next, we compared the constrained individual model and unconstrained model for each path. We analyzed whether there were significant differences between the path coefficients by group through the chi-square difference between the two models.

\section{Data Analysis and Results}

\subsection{Measurement Model Assessment}

First, we assessed the acceptability of the brand experience scale developed for existing products or services regarding the city brand experience. For this, confirmatory factor analysis was conducted on the items of city brand experience, which indicated that the measurement model was adequate $($ Chi-square $=169.214$, degrees of freedom $($ d.f). $=48$; goodness-of-fit index $[\mathrm{GFI}]=0.92 ;$ normed fit index $[\mathrm{NFI}]=0.957$; comparative fit index $[\mathrm{CFI}]=0.969$; and root mean square error of approximation $[$ RMSEA $]=0.088$, see Table 3 ).

Table 3. Description of city brand experience.

\begin{tabular}{lcccccc}
\hline & $\boldsymbol{\beta}$ & S.E. & C.R. & $\mathbf{P}^{\mathbf{1}}$ & AVE & CR \\
\hline Sensitive & 0.895 & & & & & \\
& 0.88 & 0.041 & 22.393 & $* * *$ & 0.64 & 0.842 \\
& 0.785 & 0.045 & 18.15 & $* * *$ & & \\
\hline Affective & 0.912 & & & & & \\
& 0.933 & 0.034 & 28.757 & $* * *$ & 0.749 & 0.9 \\
& 0.908 & 0.035 & 26.761 & $* * *$ & & \\
\hline Behavioral & 0.786 & & & & & \\
& 0.908 & 0.059 & 18.501 & $* * *$ & 0.643 & \\
& 0.907 & 0.061 & 18.464 & $* * *$ & & \\
\hline Intellectual & 0.848 & & & & & \\
& 0.947 & 0.045 & 23.975 & $* * *$ & 0.721 & \\
& 0.926 & 0.045 & 23.162 & $* * *$ & &
\end{tabular}

Next, we assessed the acceptability of the measurement model according to the reliability of individual items, internal consistency between the items of all constructs, and the model's convergent and discriminant validity. Confirmatory factor analysis indicated that the measurement model was adequate (Chi-square $=222.954 ;$ d.f. $=71 ; \mathrm{GFI}=0.910 ; \mathrm{NFI}=0.949 ; \mathrm{CFI}=0.964 ;$ and RMSEA $=0.081$ ). All constructs were tested for reliability via the Cronbach's alpha reliability test. As indicated by the results in Table 4, the Cronbach's alphas of the tested constructs ranged from 0.847 (City Brand Ambassadorship Behavior Intention) to 0.954 (City Brand Experience).

The average variance extracted (AVE) values of the variables, Cronbach's alphas, and composite reliability (CR) of all constructs exceeded the threshold values suggested by previous research [39,40]. Table 4 reports the measures and the convergent validity of the test results. Next, we tested the significance of the hypothesized relationships and found significant correlation coefficients (Table 5). 
The square root of the AVE value is larger than other correlation coefficients of the neighboring horizontal and vertical axes, and all the coefficients satisfy the standard value.

Table 4. Reliability analysis and AVE.

\begin{tabular}{cccc}
\hline Constructs $^{1}$ & AVE & CR & Cronbach' $\boldsymbol{\alpha}^{\mathbf{1}^{\prime}}$ \\
\hline CBE & 0.615 & 0.864 & 0.954 \\
SCC & 0.672 & 0.891 & 0.941 \\
SA & 0.715 & 0.883 & 0.923 \\
CBABI & 0.542 & 0.777 & 0.847
\end{tabular}

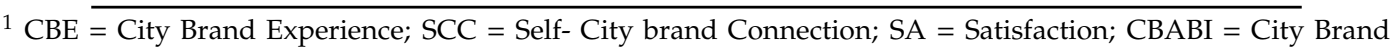
Ambassadorship Behavior Intention.

Table 5. Analysis of discriminant validity.

\begin{tabular}{ccccc}
\hline & CBE $^{\mathbf{1}}$ & SCC & SA & CBABI \\
\hline CBE & $\mathbf{0 . 7 8 4}$ & & & \\
SCC & $0.546^{* *}$ & $\mathbf{0 . 8 1 8}$ & & \\
SA & $0.539^{* *}$ & $0.502^{* *}$ & $\mathbf{0 . 8 4 5}$ & $\mathbf{0 . 7 3 6}$ \\
CBABI & $0.598^{* *}$ & $0.486^{* *}$ & $0.619^{* *}$ & . \\
\hline \multicolumn{2}{c}{${ }^{* *} p<0.01 .^{2}$ The numbers in bold represent the square root of the AVEs. }
\end{tabular}

\subsection{Hypotheses Testing}

The data supports $\mathrm{H} 1$ as it shows that self-city connection has a significant effect on city brand experience $(\alpha=0.751, \rho<0.001)$. The data also show that self-city connection is related to satisfaction $(\alpha=0.263, \rho<0.001)$. Though the results support H1 and H2, we could not find any relationship between self-city connection and CBABI $(\alpha=-0.097, \rho>0.05)$, meaning that $\mathrm{H} 3$ is not supported.

In the second part of the proposed model, the data reveal a significant relationship between city brand experience and city satisfaction $(\alpha=0.561, \rho<0.001)$; thus, $\mathrm{H} 4$ is supported. City brand experience was found to have a significant effect on CBABI $(\alpha=0.47, \rho<0.001)$, indicating that $\mathrm{H} 5$ is supported. The data illustrates a significant effect of city satisfaction on CBABI $(\alpha=0.561, \rho<0.001)$, providing support for H6. See Table 6 and Figure 2.

Table 6. Analysis Results.

\begin{tabular}{ccccc}
\hline Hypothesized Relationship & $\boldsymbol{\beta}^{\mathbf{1 , 2 , 3}}$ & S.E. & C.R. & Remark \\
\hline H1 SCC $\rightarrow$ CBE & $0.751^{* * *}$ & 0.043 & 13.554 & Supported \\
H2SCC $\rightarrow$ SA & $0.263^{* * *}$ & 0.063 & 3.719 & Supported \\
H3SCC $\rightarrow$ CBABI & -0.097 & 0.063 & -1.616 & Not supported \\
H4 CBE $\rightarrow$ SA & $0.561^{* * *}$ & 0.089 & 7.269 & Supported \\
H5 CBE $\rightarrow$ CBABI & $0.47^{* * *}$ & 0.087 & 6.036 & Supported \\
H6 SA $\rightarrow$ CBABI & $0.561^{* * *}$ & 0.063 & 8.671 & Supported \\
\hline
\end{tabular}

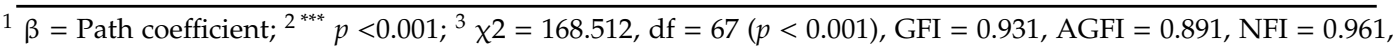
$\mathrm{IFI}=0.976, \mathrm{CFI}=0.976, \mathrm{RMR}=0.068$. 


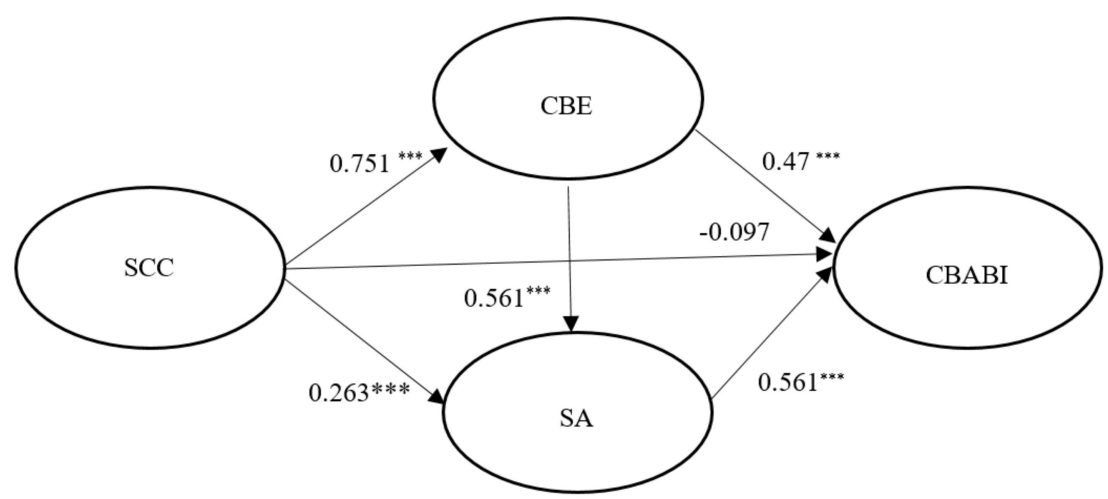

Figure 2. Path coefficient for the hypothesized relationships in the model. Note: ${ }^{* *} p<0.001$.

Additionally, this study conducted SEM (structural equation modeling) multiple group analysis to identify the differences between Seoul and Busan. The Chi-square difference between the unconstrained model and the all-constrained model is $17.765(\mathrm{df}=6, p<0.01)$, which means that there is a significant difference between the two models (see Table 7).

Table 7. SEM multiple group analyses.

\begin{tabular}{cccccc}
\hline Model & $\chi^{2}$ & $d f$ & RMSEA & CFI & TLI \\
\hline Unconstrained model & 300.824 & 150 & 0.056 & 0.966 & 0.958 \\
All-constrained model & 318.589 & 156 & 0.057 & 0.963 & 0.957 \\
Difference & 17.765 & 6 & 0.001 & 0.003 & 0.001 \\
\hline
\end{tabular}

Follow-up tests constraining individual covariance paths one at a time were conducted again. Six additional nested models (P1-P6) were used. While the overall analysis of the structural covariance model had sufficient power to produce a significant Chi-square, the P6 (H6) path was found to differ significantly between the groups when they were individually tested $(p<0.001)$. The effects of satisfaction on CBABI were positive in both cities, but it was found to have a more considerable influence in Busan. Furthermore, the effect of city brand experience on CBABI, as hypothesized by H6, was higher in Seoul (See Tables 8 and 9).

Table 8. Constrained individual covariance paths analysis.

\begin{tabular}{|c|c|c|c|c|c|c|}
\hline Models (Paths) & $x^{2}$ & $\Delta x 2^{1}$ & DF & TLI & CFI & RMSEA \\
\hline $\mathrm{P} 1(\mathrm{SCC} \rightarrow \mathrm{CBE})$ & 301.835 & 1.001 & 151 & 0.958 & 0.966 & 0.055 \\
\hline P2 $(\mathrm{SCC} \rightarrow \mathrm{SA})$ & 301.039 & 0.215 & 151 & 0.959 & 0.966 & 0.055 \\
\hline P3 $(\mathrm{SCC} \rightarrow \mathrm{CBABI})$ & 301.03 & 0.206 & 151 & 0.959 & 0.966 & 0.055 \\
\hline $\mathrm{P} 4(\mathrm{CBE} \rightarrow \mathrm{SA})$ & 300.902 & 0.078 & 151 & 0.959 & 0.966 & 0.055 \\
\hline P5 (CBE $\rightarrow$ CBABI) & 304.122 & 3.298 & 151 & 0.958 & 0.965 & 0.056 \\
\hline P6 $(\mathrm{SA} \rightarrow \mathrm{CBABI})$ & 312.012 & $11.188^{* * *}$ & 151 & 0.956 & 0.963 & 0.057 \\
\hline
\end{tabular}


Table 9. Standard regression weights: Multiple group test results.

\begin{tabular}{cccc}
\hline Hypotheses & All & Seoul & Busan \\
\hline H1 & $0.751^{* * *}$ & $0.695^{* * *}$ & $0.781^{* * *}$ \\
H2 & $0.263^{* * *}$ & $0.321^{* * *}$ & $0.276^{* *}$ \\
H3 & $-0.097^{* * *}$ & $-0.087^{* * *}$ & -0.022 \\
H4 & $0.561^{* * *}$ & 0.52 & $0.526^{* * *}$ \\
H5 & $0.47^{* * *}$ & $0.601^{* * *}$ & $0.265^{* *}$ \\
H6 & $0.561^{* * *}$ & $\mathbf{0 . 4 1 9}$ & $\mathbf{0 . 7 1 7 ^ { * * * }}$ \\
\hline & $1^{* * *} p<0.001^{* *} p<0.01$.
\end{tabular}

\section{Discussion}

This study examined the effect of city brand experience and self-city brand connection on residents satisfaction in their city. Self-city brand connection was found to have a positive effect on city brand experience and satisfaction. Previous studies $[23,41]$ found that self-city brand connection has a positive effect on consumer responses. The results of this study can be interpreted as an extension of those previous studies. As with general brands, the more the residents of a city are connected with it and regard it as part of them, the higher the level of satisfaction and the more positive the experience with the city. However, we could not find a direct relationship between self-city brand connection and CBABI. Additionally, we verified indirect effects on the relationship between the self-city brand connection and the CBABI. From analyzing the two-path mediated effect, the indirect effect of brand experience was not significant in the relationship between self-city brand connection and CBABI $(\beta=-0.044$, $p>0.01)$. Conversely, indirect effects on the path of self-city brand connection-satisfaction-CBABI were significant $(\beta=0.128, p<0.01)$. Therefore, it was confirmed that satisfaction plays a role as a mediator in the relationship between self-brand connection and CBABI.

According to our results, self-city brand connection affects city brand experience, and city brand experience affects CBABI. This suggests the importance of the city brand experience. City brand experiences were found to have significant effects on satisfaction and CBABI. Furthermore, satisfaction had a positive effect on CBABI.

Previous studies on brand experience have found that brand experience has a positive effect on satisfaction or brand loyalty $[13,42]$. The results of the current study reveal that city brand experiences lead to positive responses from citizens, which can have a positive effect on cognitive aspects and related behaviors, such as participating in city activities.

Finally, this study verified the difference between Seoul and Busan, the largest cities in Korea. For Busan, the effect of city brand satisfaction on CBABI was higher than in Seoul. This suggests that the effect route of city brand experience may differ for each city. Kazançoğlu and Dirsehan [43] analyzed the dimension of city brand experiences between two major cities in Turkey, Istanbul, and Izmir. Their results indicated clear differences between these cities; for example, Istanbul's social activities and leisure time experience are stronger than Izmir's. Future urban brand research will need to consider the characteristics of each city and the dimension of brand experience.

\section{Conclusions}

Although most studies related to city branding have a broad and diversified perspective, research on resident-oriented city brand experience is minimal. Thus, this study examined the effect process centering on the brand experience and the participation of city residents. The academic and practical implications of this study are listed below.

This study makes an academic contribution in that it theoretically extends the discussion of brand experience in traditional marketing to city brand research. While various concepts in brand research have been accepted and applied to city brand research, the literature on brand experience is limited. This study distinguishes itself by providing academic convergence between brand experience and 
the city's brand. Additionally, this study makes a theoretical contribution in that it examines brand experience centered on residents of cities. In reality, city branding is being developed in the direction of citizen participation and sharing [28]. This study found discriminatory values and made theoretical contributions to the current resident-centered research.

Furthermore, this study's value can be found in the theoretical significance of the effect of residents on the satisfaction of the city. Urban citizens are now more than just passive beneficiaries or place customers but partners in the city's public goods, services, and policies [44]. Therefore, residents' satisfaction is a crucial factor in city branding [45], but studies on city residents' satisfaction are scarce [27]. Therefore, this study can confirm the theoretical significance of this study in that it comprehensively identified the variables that affect the urban brand satisfaction of residents.

In practice, the results of this study are expected to provide specific implications for the establishment of city brand strategies for local governments that spur city branding. As well established brand experiences that companies provide to consumers become a major contributor to brand loyalty [46], well-managed city brand experiences are the starting point of a city brand strategy, and they turn residents into city brand ambassadors.

Based on recent studies related to city branding [31,47], sufficient participation and communication of various stakeholders for a city's sustainability and survival are needed. This study examined the preceding variables influencing residents' participation in city brand ambassadors to identify the importance of participation in city branding and the relationship between other variables. The results of this study suggest that city brand marketers should strengthen their activities to enhance the brand experience and satisfaction of residents to participate with city brand ambassadors.

Despite the value of this study, it has some limitations. First, it only examines residents in their 20s, 30s, and 40s in Seoul and Busan. Future research should measure the brand experiences of more diverse urban and age group residents and verify effect paths. Second, based on previous research, this study used product and service brand experience as a measure of city brand experience; however, future studies will need to consider the development and use of city brand experience scales considering a city's specific characteristics.

Author Contributions: The authors contributed equally to this work. All authors have read and agreed to the published version of the manuscript.

Funding: This research received no external funding.

Conflicts of Interest: The authors declare no conflict of interest.

\section{References}

1. Ritchie, J.R.B.; Hudson, S. Understanding and meeting the challenges of consumer/tourist experience research. Int. J. Tour. Res. 2009, 11, 111-126. [CrossRef]

2. Green, A.; Grace, D.; Perkins, H.; Green, D.G.A. City branding research and practice: An integrative review. J. Brand Manag. 2016, 23, 252-272. [CrossRef]

3. Bose, S.; Roy, S.K.; Alwi, S.F.S.; Nguyen, B. Measuring customer-based place brand equity (CBPBE) from a public diplomacy perspective: Evidence from West Bengal. J. Bus. Res. 2018. [CrossRef]

4. Tugulea, O. City Brand Personality-Relations with Dimensions and Dimensions Inter-Relations. Sustainability 2017, 9, 2243. [CrossRef]

5. Soo, K.B.; Na, J.-H.; 인형; 양수. A Study on the Influence of City Attributes on Revisit Intention: The Mechanism Test of City Brand Personality. J. Prod. Res. 2016, 34, 9-15.

6. Botschen, G.; Promberger, K.; Bernhart, J. Brand-driven identity development of places. J. Place Manag. Dev. 2017, 10, 152-172. [CrossRef]

7. Lee, Y.J.; Han, E.K. An exploratory study for development of a city reputation scale: Focusing on stakeholder relationships. Advert. Res. 2010, 87, 392-415.

8. Rehmet, J.; Dinnie, K. Citizen brand ambassadors: Motivations and perceived effects. J. Destin. Mark. Manag. 2013, 2, 31-38. [CrossRef] 
9. Zenker, S.; Beckmann, S.C. Measuring brand image effects of flagship projects for place brands: The case of Hamburg. J. Brand Manag. 2013, 20, 642-655. [CrossRef]

10. Braun, E.; Kavaratzis, M.; Zenker, S. My city - my brand: the different roles of residents in place branding. J. Place Manag. Dev. 2013, 6, 18-28. [CrossRef]

11. Klaus, P.P.; Maklan, S. Towards a Better Measure of Customer Experience. Int. J. Mark. Res. 2013, 55, $227-246$. [CrossRef]

12. Barnes, S.J.; Mattsson, J.; Sørensen, F. Destination brand experience and visitor behavior: Testing a scale in the tourism context. Ann. Tour. Res. 2014, 48, 121-139. [CrossRef]

13. Brakus, J.J.; Schmitt, B.H.; Zarantonello, L. Brand experience: what is it? How is it measured? Does it affect loyalty? J. Mark. 2009, 73, 52-68.

14. Schmitt, B. Experiential Marketing. J. Mark. Manag. 1999, 15, 53-67. [CrossRef]

15. Gentile, C.; Spiller, N.; Noci, G. How to sustain the customer experience: An overview of experience components that co-create value with the customer. European Manag. J. 2009, 25, 395-410.

16. Kumar, V.; Kaushik, A.K. Destination brand experience and visitor behavior: The mediating role of destination brand identification. J. Travel \& Tour. Mark. 2018, 35, 649-663.

17. Jeon, K.H.; Oh, Y.-T. Effects of Experiential Factors for a City Brand Evaluation. J. Prod. Res. 2015, 33, 41-47.

18. Lee, M.H. The effect of emotion, consumer-brand relationship and brand loyalty on travel consumer's experiential value. Tour. Manag. Res. 2017, 76, 235-256.

19. Berry, L.L. Cultivating Service Brand Equity. J. Acad. Mark. Sci. 2000, 28, 128-137. [CrossRef]

20. Freire, J.R. 'Local people'a critical dimension for place brands. J. Brand Manag. 2009, 16, 420-438. [CrossRef]

21. Hospers, G. Making sense of place: from cold to warm city marketing. J. Place Manag. Dev. 2010, 3, $182-193$. [CrossRef]

22. Escalas, J.E.; Bettman, J.R. You Are What They Eat: The Influence of Reference Groups on Consumers' Connections to Brands. J. Consum. Psychol. 2003, 13, 339-348. [CrossRef]

23. Ferraro, R.; Escalas, J.E.; Bettman, J.R. Our possessions, our selves: Domains of self-worth and the possession-self link. J. Consum. Psychol. 2011, 21, 169-177. [CrossRef]

24. Park, C.W.; MacInnis, D.J.; Priester, J.; Eisingerich, A.B.; Iacobucci, D. Brand Attachment and Brand Attitude Strength: Conceptual and Empirical Differentiation of Two Critical Brand Equity Drivers. J. Mark. 2010, 74, 1-17. [CrossRef]

25. Kemp, E.; Childers, C.Y.; Williams, K.H. Place branding: creating self-brand connections and brand advocacy. J. Prod. Brand Manag. 2012, 21, 508-515. [CrossRef]

26. Zenker, S.; Rütter, N. Is satisfaction the key? The role of citizen satisfaction, place attachment and place brand attitude on positive citizenship behavior. Cities 2014, 38, 11-17. [CrossRef]

27. Zenker, S.; Petersen, S.; Aholt, A. The Citizen Satisfaction Index (CSI): Evidence for a four basic factor model in a German sample. Cities 2013, 31, 156-164. [CrossRef]

28. Koo, J.R. New paradigm of city branding, open source branding. Marketing 2016, 50, $21-27$.

29. Hawkins, C.V.; Wang, X. Sustainable development governance: Citizen participation and support networks in local sustainability initiatives. Public Works Manag. E Policy 2012, 17, 7-29.

30. Portney, K.E.; Berry, J.M. Participation and the Pursuit of Sustainability in U.S. Cities. Urban Aff. Rev. 2010, 46, 119-139. [CrossRef]

31. Dastgerdi, A.S.; De Luca, G. Strengthening the city's reputation in the age of cities: an insight in the city branding theory. City, Territ. Arch. 2019, 6, 2-7. [CrossRef]

32. Stylidis, D. The role of place image dimensions in residents' support for tourism development. Int. J. Tour. Res. 2016, 18, 129-139. [CrossRef]

33. Ambroise, L.; Pantin-Sohier, G.; Valette-Florence, P.; Albert, N. From endorsement to celebrity co-branding: Personality transfer. J. Brand Manag. 2014, 21, 273-285. [CrossRef]

34. Andersson, M.; Ekman, P. Ambassador networks and place branding. J. Place Manag. Dev. 2009, 2, 41-51. [CrossRef]

35. Pebriani, N.L.P.D.A.; Hernando, A.; Junarta, R. The role of 'Abang-None' Jakarta as brand ambassador in enhancing positive image of thousand islands. Res. Society Dev. 2010, 9, 183911914.

36. Taecharungroj, V. City ambassadorship and citizenship behaviours: modelling resident behaviours that help cities grow. J. Place Manag. Dev. 2016, 9, 331-350. [CrossRef] 
37. Choi, J.H.; Lee, H.B.; Kim, Y.K. Perception differences on city brand between residents and non-residents with different types of experiences: Impact on the city brand image and likability. Korean J. Communication Studies 2017, 25, 155-182.

38. Kline, R.B. Principles and Practice of Structural Equation Modeling, 2nd ed.; Guilford Press: New York, NY, USA, 2005.

39. Fornell, C.; Larcker, D.F. Structural equation models with unobservable variables and measurement error: Algebra and statistics. J. Mark. Res. 1981, 18, 382-388. [CrossRef]

40. Hair, J.F.; Black, W.C.; Babin, B.J.; Anderson, R.E.; Tatham, R.L. Multivariate Data Analysis, 5th ed.; Prentice Hall: Upper Saddle River, NJ, USA, 1998.

41. Fournier, S. Consumers and Their Brands: Developing Relationship Theory in Consumer Research. J. Consum. Res. 1998, 24, 343-353. [CrossRef]

42. Iglesias, O.; Singh, J.J.; Batista-Foguet, J.M. The role of brand experience and affective commitment in determining brand loyalty. J. Brand Manag. 2011, 18, 570-582. [CrossRef]

43. Kazançoğlu, Đ.; Dirsehan, T. Exploring brand experience dimensions for cities and investigating their effects on loyalty to a city. Bus. E Economics Res. J. 2014, 5, 17-37.

44. Insch, A. Managing residents' satisfaction with city life: Application of Importance-Satisfaction analysis. J. Town \& City Manag. 2010, 1, 164-174.

45. Zenker, S.; Martin, N. Measuring success in place marketing and branding. Place Brand. Public Dipl. 2011, 7, 32-41. [CrossRef]

46. Ismail, A.R.; Melewar, T.; Lim, L.; Woodside, A. Customer experiences with brands: Literature review and research directions. Mark. Rev. 2011, 11, 205-225. [CrossRef]

47. Dastgerdi, A.S.; De Luca, G.; Dastgerdi, S.; Luca, D. Joining Historic Cities to the Global World: Feasibility or Fantasy? Sustain. 2019, 11, 2662. [CrossRef]

(C) 2020 by the authors. Licensee MDPI, Basel, Switzerland. This article is an open access article distributed under the terms and conditions of the Creative Commons Attribution (CC BY) license (http://creativecommons.org/licenses/by/4.0/). 